\title{
Creating Awareness of Sexual Abuse in Children with Special Education Needs: Depending on the Opinions of Teachers of the Mentally Handicapped
}

\author{
Çağla Girgin Büyükbayraktar ${ }^{1}$, Rukiye Konuk Er $^{2}$, Şahin Kesici ${ }^{2}$ \\ ${ }^{1}$ College of Applied Science, Selcuk University, Beysehir-Konya, Turkey \\ ${ }^{2}$ School of Education, Necmettin Erbakan University, Konya, Turkey \\ Correspondence: Rukiye Konuk Er, School of Education, Necmettin Erbakan University, Konya, Turkey.
}

Received: December 4, 2017

Accepted: December 28, 2017 Online Published: December 29, 2017

doi:10.11114/jets.v6i1.2841

URL: https://doi.org/10.11114/jets.v6i1.2841

\begin{abstract}
The purpose of this research is to determine what students and families should do in order to prevent sexual abuse in students who need special education, depending on the opinions of teachers of mentally handicapped students. The qualitative research technique was used in this research. The study population of the research consisted of the teachers of mentally handicapped individuals working in Turkey/Konya province. The study population included 35 teachers. Semi-structure interview method was used as data collection method in collecting data in the research. According to the results, it is evident that individuals ought to be taught about their private parts, private parts in their bodies, and they ought to be made conscious about the fact that no one can touch these private parts in order to raise awareness about sexual abuse in individuals with special education needs. In order to stop sexual abuse by raising awareness in families of individuals with special education needs, it is necessary for families to acquire skills in terms of knowing their children, determining their needs and consulting an expert periodically. In order to raise awareness in the community about the sexual abuse in individuals with special education needs, the teachers express that all families should be trained, seminars should be organized on the issue and media ought to do its part to create awareness.
\end{abstract}

Keywords: teachers of mentally handicapped children, sexual abuse, parents

\section{Introduction}

Sexual abuse towards a child is an action which is done for sexual satisfaction or for a sexual purpose and in which a child is used or it is attempted to use a child (Fowler, 2008; Walsh, Zwi, Woolfenden \& Shlonsky, 2015; WHO, 1999). When a child feels that $\mathrm{s} / \mathrm{he}$ is sexually abused, it is a sexual abuse, even if $\mathrm{s} / \mathrm{he}$ cannot identify whether the behavior is sexual abuse it specifically because of lack of understanding and his/her age. Misuse might happen once or it might be a continual sexual abuse which extends over a long period (Fowler, 2008:17). It is possible to characterize sexual abuse in children in different ways which determine whether an incident is accepted to be a sexual abuse or not. The first condition is lack of consent. Children do not have the maturity to give permission sexual activity. Another condition is misuse. Children might be manipulated or forced into sexual behaviors by stronger, more skillful or more knowledgeable adults (Kinnear, 2007:3). So emerging adulthood's period is not appear these children (Özteke-Kozan \& Hamarta, 2017).

When it comes to disability, children with disabilities are more vulnerable to sexual abuse since they experience deficiencies in understanding and interpreting events; additionally, they cannot control their sexual drive and they need special interest about sexuality (Yıldırım-Doğru, 2006). Sexual harassment and assault of children with physical and developmental disabilities is quite common (Krohn, 2014). In a research conducted by Baladerian, Colemand and Stream (2013) on 1300 people with disabilities, it has been revealed that $41.6 \%$ of individuals with disabilities are sexually abused. In addition, in another study which was conducted on how individuals with abilities were victimized, it is stated that the possibility of being sexually abused for children with disabilities is 2.9 times higher in comparison with children without disabilities (Stalker \& McArthur, 2012; Smith \& Harrell, 2013). The risk of sexual abuse for mentally handicapped children is 4.6 times more than their peers with disabilities (Smith \& Harrell, 2013). Besides, as the severity of an individual's disability increases, the possibility of being exposed to sexual abuse also increases (Bensy, 2011).

This issue has not caught the attention of politicians, experts, advocates or members of the public because of various 
factors such as: children with disabilities experience difficulties in expressing situations related to abuse; it is easier to get them take advantage of them by comparison with other sufferers; and, the possibility of receiving support is low for them (Smith \& Harrell, 2013). Nevertheless, there has been an increasing interest in the risk of abuse of individuals with disabilities for the last 20 years. The society has begun to accept that abuse is a serious problem (Thornberry \& Olson, 2005). Amendatory services and criminal justice systems are generally unsuccessful in meeting the needs of children with disabilities. There have been limited numbers of studies concerning abuse and protection of children with disabilities (Stalker \& McArthur, 2012).

It is thought that teachers are an important factor in preventing child sexual abuse (Claudia \& Martine, 2014). At this point, special education teachers believe that students with disabilities are at the risk of sexual abuse (Kliethermes, 2003; Konuk Er, Büyükbayraktar, Kesici, 2016). With reference to this opinion, sexual abuse of children who spend most of their time at school inevitably happens at school (Krohn, 2014). It is stated that most of the students with disabilities who are exposed to sexual abuse experience severe abuse once at least in a school environment and sexual abuse continues to happen in different environments (Bensy, 2011).

Zemp (2002) believes that lack of sexual knowledge also poses a risk factor for sexual abuse. In addition, Davis (2011) believes that in order to prevent abuse, individuals such as those with disabilities themselves, families, lawyers, judges, public prosecutors and police officers should be encouraged to receive training on abuse. Further, children with disabilities should receive education at an early age in order to understand abuse and avoid it. In addition, family assistance schemes should be established to prevent the abuse of the disabled person by taking a break from the day-to-day care responsibility, which directly affects disabled families such as day care and becomes more difficult. There is a need for developing a more successful, integrated approach in order to prevent sexual abuse. Such an approach must consider individual needs of children, a balance between a healthy sexual development and protection from sexual abuse (Krohn, 2014). From this point of view, the purpose of this study is to determine what students and their families must do in order to prevent sexual abuse that students with special education needs are exposed to, depending on the opinions of teachers of the mentally handicapped. In order to achieve this goal, this qualitative research attempted to respond to the following questions:

1- What skills do you think must be developed in children with special education needs in order to create the awareness of sexual abuse?

2- What skills do you think families of children with special education needs must gain in order to raise awareness in terms of preventing child sexual abuse?

3- What points do you think must be considered in order to create awareness in the society of sexual abuse of children with special education needs?

\section{Method}

\subsection{Research Model}

Semi-structured interview method of qualitative research was used in this research. Providing sensitivity to the natural environment, researchers' roles as participants, having an integrated approach, revealing perceptions, flexibility in research design and having an inductive analysis are significant characteristics of qualitative research techniques (Yıldırım \& Şimşek, 2005). Qualitative research emphasizes the interpretation of meanings, experiences and descriptions. Comprehensive and detailed data consisting of words which are completely described and observed by individuals formed the primary part of this research (Coolican, 1992).

\subsection{Research Group}

In this research, purposive sampling method was used. Obtaining extensive and detailed information about what sexual problems people with special education needs experience and how sexual education for these students must be provided depending on the opinions of teachers of mentally handicapped individuals is the reason why this sampling method is preferred (Yıldırım \& Şimşek, 2005). Criteria for the selection of teachers for the working group were determined and these criteria are those who work in special education institutions and volunteer to participate in the research.. The research was conducted using information provided by teachers of the mentally handicapped who have been working in Special Education Schools and Counseling and Guidance Centers which belong to the central districts of Konya province. The research group consists of 35 teachers: 22 of these teachers are female, 13 of them are male. Considering the ages of these teachers, it is seen that 11 of them are in 25-30 age range, 8 of them are in 31-35 age range, 7 of them are in 36-40 age range, 9 of them are in 46 and over age range. When years of working experience of the teachers are considered, it is seen that 2 people have 1-year working experience, 1 person has 2 -year working experience, 8 people have 3-year working experience, 3 people have 4-year working experience, 3 people have 5 -year working experience, 2 people have 6-year working experience, 1 person has 7-year working experience, 7 people have 8 -year working 
experience, 1 person has 9-year working experience, 3 people have 10-year working experience, 1 person has 11 -year working experience, 1 person has 13 -year working experience and 2 people have 15 -year working experience.

\subsection{Semi-structured Interview Technique}

In the research, semi-structured interview method was used as the data collection method in collecting data and the related literature was reviewed. In the literature, emphasis was put on sexual abuse of students with special education needs and with particular attention to how it can be prevented. Children with disabilities are more vulnerable to sexual abuse because they experience deficiencies in understanding and interpreting incidents; moreover, they cannot control their sexual drives and they need special care in learning about sexuality (Kvam, 2004). Starting from this point, the related themes are: which skills must be acquired by individuals with special education needs in order to create awareness of sexual abuse; which skills must be gained by families in order to prevent sexual abuse of their children; and, the which interventions must take place in order to create awareness in society about sexual abuse of individuals with disabilities were determined and a semi-structured interview form was developed using questions which might measure these themes.

In order to ensure the validity of the interview form, interview form was given to five faculty members working at the Faculty Education of Necmettin Erbakan University. The semi-structured form was constructed in the direction of the opinions offered by the faculty members. After that, pilot practices were conducted and the interview forms became ready for use in consequence of corrections which were made according to the results obtained. Practices were collected from the teachers in writing. It is significant for validity to include quotations from individuals and explain the results with these quotes for this purpose, some of the data obtained from the research were presented as they are in order to provide the credibility (Wolcott, 1990).

\subsection{Data Collection}

Interviews were conducted on a voluntary basis. An explanation was prepared for the interviews was offered, the purpose of the research and how the research would be done was stated in it. It was also emphasized that the identities of the participant would remain hidden. Written interview forms were used during the interviews. The interviews lasted for 20-25 minutes.

\subsection{Data Analysis and Interpretation}

The collected data were analyzed using the content analysis technique. The main purpose in the content analysis was to get concepts and relationships which might explain the collected data and respond to the research questions.

What is done in the content analysis is clearly organizing similar data by gathering them within the frame of certain concepts and themes and interpreting them. For this purpose, first of all, the data were conceptualized, and then they were arranged logically according to the obtained concepts and the themes describing the data were determined (Tavşancıl \& Aslan, 2001; Yıldırım \& Şimşek, 2005).

The opinions of the participants were recorded into the semi-structure forms in writing. Each interview was numbered, starting with number 1 . While reading the data, words, sentences and paragraphs, information was coded by conceptualizing in order to determine the intended idea (Brott \& Myers, 2002). Coding was carried out within the frame of the research purpose and interview questions. During coding, "computer assisted qualitative data analysis program Nvivo7" was used. The categories are used to analyze and compare various meanings in a category which is formed at the lowest level. The unique richness of the items in this category exhibits qualitative analyses as they are (Coolican, 1992). The themes concerning: the skills which must be acquired by individuals with special education needs in order to create awareness about sexual abuse; the skills which must be gained by families in order to prevent sexual abuse of their children; and the things which must be done in order to create awareness in the society of sexual abuse of individuals with disabilities were determined according to the related the literature for this research. The themes were categorized into subcategories. Opinions of teachers associated with each category were included.

\section{Results}

The things to be done by children and families in order to prevent sexual abuse of children with special education needs were analyzed as to the opinions expressed by the teachers in accordance with the three themes mentioned (awareness of sexual abuse of children with disabilities, awareness in families of sexual abuse of children with disabilities, awareness in the society of sexual abuse of children with disabilities) and were determined in the direction of these opinions. Afterwards, these three themes were categorized. Opinions related to each category were included. Findings, themes, themes related to the categories, number of teachers expressing their opinions related the categories and sample opinions of teachers are given in Table 1. 


\subsection{The Theme of Awareness of Sexual Abuse in Children with Disabilities}

The theme of awareness of sexual abuse in children with disabilities consists of 5 categories. These categories are: teaching privacy regions in human body (privacy), avoiding physical contact, informing about sexual abuse, informing families, informing about sexuality and gender differences. Among 35 teachers who participated in the research: 11 of them expressed their opinions on "avoiding physical contact", 8 of them delivered opinions on "teaching privacy regions in human body", 6 of them presented their opinions on "sexual abuse", 5 of them expressed opinions on "informing families", 5 of them expressed opinions on "sexuality and gender differences". Sample opinions of teachers concerning these categories are given in Table 1.

\subsection{The Theme of Awareness in the Family of Sexual Abuse of Children with Disabilities}

The theme of awareness in the family of sexual abuse of children with disabilities consists of 5 categories. These categories are: teaching a child privacy regions in his/her body, family training/awareness, knowing a child well, observation/following skills, and awareness of sexual needs. Among 35 teachers who participated in the research, 12 of them expressed opinions on "family training/awareness", 7 of them delivered opinions on "knowing a child well", 6 of them presented opinions on "observation/following skills", 5 of them expressed opinions on "teaching a child privacy regions in his/her body", 5 of them expressed opinions on "awareness of sexual needs". Sample opinions of teachers concerning these categories are shown in Table 1.

\subsection{The Theme of Awareness in the Society of Sexual Abuse of Children with Disabilities}

The theme of awareness in society of sexual abuse of children with disabilities includes 4 categories. These categories are: by the government, through seminars and informative meetings, through media and through families. Among 35 teachers, 14 of them expressed their opinions on "through seminars and informative meetings", 9 of them delivered opinions on "through media", 7 of them expressed opinions about "through families", 5 of them presented their opinions about the category of "by the government". Sample opinions of teachers related to these categories are given in Table 1.

Table 1. Opinions of Teachers of the Mentally Handicapped about the Things To Be Done by Students and Their Families in order to Prevent Sexual Abuse of Children with Education Needs

\begin{tabular}{|c|c|c|c|c|}
\hline Themes & & Categories & $\begin{array}{l}\text { Number of } \\
\text { teachers } \\
\text { participated in } \\
\text { the categories }\end{array}$ & Sample Opinions of Teachers of The Mentally Handicapped \\
\hline \multirow[t]{5}{*}{$\begin{array}{l}\text { Awareness } \\
\text { Children } \\
\text { Disabilities } \\
\text { Sexual Abuse }\end{array}$} & \multirow[t]{5}{*}{$\begin{array}{r}\text { in } \\
\text { with } \\
\text { of }\end{array}$} & $\begin{array}{l}\text { Teaching privacy regions } \\
\text { in human body(privacy) }\end{array}$ & 8 people & $\begin{array}{l}\text { "An individual should be taught about his/her privacy } \\
\text { regions, private parts in his/her body should be taught. It } \\
\text { should be taught that no one can see these privacy regions } \\
\text { and a doctor can see them if only family members } \\
\text { accompany them"(Ö1). } \\
\text { "I emphasize that if there is a contact with one of those } 3 \\
\text { regions including genital region, breast and a possible } \\
\text { region appropriate for sexual abuse, it is necessary to ask } \\
\text { for help" (Ö13). }\end{array}$ \\
\hline & & \multirow{2}{*}{$\begin{array}{l}\text { Avoiding physical contact } \\
\text { (teaching a child that } \\
\text { his/her body is his/hers and } \\
\text { no one can not touch } \\
\text { his/her body. } \\
\text { Informing about sexual } \\
\text { abuse }\end{array}$} & 11 people & $\begin{array}{l}\text { "Children should be informed about to which regions in } \\
\text { their bodies they must not let others touch" } \\
\text { "The feeling that their body is theirs must be taught to } \\
\text { children and it must be told them that other people cannot } \\
\text { touch to their specific regions" (Ö35). }\end{array}$ \\
\hline & & & 6 people & $\begin{array}{l}\text { "They should gain skills such as sensitivity to sexual abuse, } \\
\text { empathy"(Ö4). } \\
\text { "Children's skills related to understanding and } \\
\begin{array}{l}\text { comprehending what is sexual abuse and } \\
\text { communication"(Ö14) }\end{array}\end{array}$ \\
\hline & & Informing Families & 5 people & $\begin{array}{l}\text { "It is necessary for families to participate in this } \\
\text { training"(Ö12). } \\
\text { "It should be explained to families having children with } \\
\text { disabilities by providing seminars"(Ö33). } \\
\text { " }\end{array}$ \\
\hline & & $\begin{array}{l}\text { Informing about sexuality } \\
\text { and gender differences }\end{array}$ & 5 people & $\begin{array}{l}\text { " } \\
\text { role which is expected from him/her, it must be provided by } \\
\text { the effect of the society and environment in which s/he } \\
\text { lives"(Ö15). }\end{array}$ \\
\hline
\end{tabular}


Awareness in the Family of Sexual Abuse of Children with Disabilities
Teaching a child privacy 5 people regions in his/her body

Family training, awareness 12 people

Knowing a child well $\quad 7$ people

Observation, Following 6 people Skills

Awareness of Sexual Needs 5 people

By the Government 5 people

Awareness in the Abuse of Children with Disabilities
"They need to know what sexuality is in order to protect themselves.

Explaining them what they can do in order to protect themselves, providing a healthy communication in which a child is open to communication and families and immediate environments do not pressure on children"(Ö19).

"It is possible to advise families to introduce their children's privacy regions, to instill their children that these regions are hidden"(Ö35).

"They should be taught about which regions are sexual regions. It should be explained to them that if someone tries to touch to these regions, they must scream, and they must ask for help from adults if they are disturbed. It must be explained that they must not contact with strangers"(Ö32)

"Families must be informed, necessary training must be provided"(Ö3).

"Families must be seriously informed by providing seminars on this topic. Experts must explain them how families should behave towards children "(Ö15).

"They must know their children well. They must determine their needs"(Ö13).

"They must know their children well. They must know the reasons of change in their children's behaviors and how to react in case of a new situation"(Ö16).

"Children must be continually observed and they must be warned about not allowing anyone to touch their privacy regions. Children should be warned by repeating this topic from time to time"(Ö2).

“Observation skills, following skills"(Ö14).

"First of all, families should help children satisfy their sexual needs"(Ö10).

"Being aware of children's sexual needs, talking to children about these issues, effective communication with children"(Ö19).

"Primarily the government must take it as its duty, emphasis must be put on this issue by beginning with kindergarten"(Ö2)

"Since it is an important issue regarding society, it must be a government policy, even a local administration policy."(Ö31)

"First of all, it can be arranged by providing seminars."(Ö5).

"Seminars must be provided primarily by experts. It must be expressed in public that it is crime"(Ö11).

Through Media 9 people

"Duty falls to media about this issue. Awareness can be provided by creating a public opinion in society by means of media"(Ö4).

"Social media must be more active about this issue and it must play a part in creating awareness"(Ö28).

Through Families $\quad 7$ people
"Colorful picture posters can be prepared and handed to families. Families become more careful, so awareness might be created in this way"(Ö15).

"The awareness must be raised, first of all, in the families of these children, then in these children, and finally in the society"(Ö29).

\section{Discussion}

Sexual abuse of children whether they have disabilities or not has been gradually increasing (Berry, Tully \& Egan, 2017; Buchana, 1991; Elkins, Gafford, Wilks, Muram \& Golden, 1986; Finkelhor, Hotaling, Lewis \& Smith, 1990).

More preventive study needs to be done than crisis intervention studies on sexual abuse that children are exposed to. This is because children with disabilities who have been exposed to unsupported sexual abuse are exposed to long-term 
effects such as post-traumatic stress disorder, anxiety, and depression, which increases the risk of bedeviled in adulthood (Smith \& Harrell, 2013; Kesici \& Baloğlu, 2017). In this research, therefore, findings and suggestions will be provided by discussing skills which will be taught by teachers of mentally handicapped individuals including skills of expression, especially inappropriate behaviors, and avoidance-protection. Awareness fields related to sexual abuse which will be taught by parents of mentally handicapped individuals to their children and each theme which occurs in order to raise awareness in the society of sexual abuse of the mentally handicapped and categories related to these themes.

The teachers of mentally handicapped children expressed their opinions on acquiring some awareness skills in order to protect mentally handicapped children from sexual abuse as to degree of disability. It is possible to conduct preventive research on their opinions which emphasize that especially mentally handicapped students should gain skills in order to protect themselves from sexual abuse by avoiding physical contact. The reason for this is if a student gains skills about to which physical regions of his/her body s/he should not allow toughing, it can be an important step in prevention of sexual abuse. According to the research conducted by Baladerian, Colemand \& Stream (2013), 92\% of special education teachers state that sexual abuse and sexual drive behaviors are observed between students-students and the most common behaviors are physical jokes.

Within the theme of awareness in the family of sexual abuse of children with disabilities, most of the teachers of the mentally handicapped children delivered opinions in the category of family training and awareness in the family. Parents fear to be obliged to take their children out and force them to live in another place because the mentioned reasons indicate that there is social pressure over families. In this situation, families are generally abusive (Davis, 2011). In addition, if a family fails in terms of knowledge, skills, resources or supporting a child's special needs and provides insufficient care and guidance, it is likely for a child to be at risk of abuse (Fisher, Hodapp \& Dykens, 2008). Sexual abuse of children has become a quite significant issue for families having special children who are very sensitive. When it is taken into consideration that the stage of accepting their children may be quite difficult for many families, this topic ought to be sensitively approached. From this point of view, it is possible to say that providing information for families and raising their awareness of sexual abuse may be significant factors.

In the theme of raising awareness in the society of sexual abuse of children with disabilities, most of the teachers of mentally handicapped individuals express that it is possible to raise awareness in the society of sexual abuse of children with disabilities through seminars and informative meetings. Since abuse is considered as a taboo that must not be mentioned, people avoid talking about sexual abuse of children (Al-Zboon \& Ahmad, 2016).

Both because of this reason and the necessity to specify (report) sexual abuse of individuals with disabilities clearly (Liou \& Chen, 2016), educators must be careful, they need to receive training related to the legal protection rights and appropriate health interventions (Tharinger, Horton, \& Millea, 1990). Seminars and informative meetings may be crucial in this regard.

\section{References}

Al-Zboon, E., \& Ahmad, J. (2016). Pre-service special education teachers' professionalism and preparation in terms of child sexual abuse. European Journal of Special Needs Education, 31(1), 13-26. https://doi.org/10.1080/08856257.2015.1087126

Baladerian, N. J., Colemand, T. F., \& Stream, J. (2013). Findings from the 2012 Survey on Abuse of People with Disabilities. Los Angeles, CA: Spectrum Institute, Disability and Abuse Project, 2013 (Accessed: 11.10. 2016), http://www. disabilityandabuse.org/survey/findings.pdf.

Bensy, M. L. (2011). Lending my voice out loud: the sexual abuse of students with disabilities in American school settings. Degree of Doctor of Education the Department of Teaching, Literacy and Leadership of Hofstra University, New York.

Berry, L. J., Tully, R. J., \& Egan, V. (2017). A Case Study Approach to Reducing the Risks of Child Sexual Exploitation (CSE). Journal of Child Sexual Abuse, 26(7), 769-784. https://doi.org/10.1080/10538712.2017.1360428

Brott, P. E., \& Myers, J. E. (2002). Development of professional school counselor identity a grounded theory. In S. B., Merriam et al. (Ed). Qualitative research in practice examples for discussion and analysis (pp. 145-160), San Francisco: Jossey-Bass A Wiley Company.

Buchana, A. (1991). Sexual abuse of the mentally handicapped: difficulties in establishing prevalence. Psychiatric Bulletin, 15, 601-605. https://doi.org/10.1192/pb.15.10.601

Claudia, B., \& Martine, H. (2014). Social Relationships in Sexually Abused Children: Self-reports and Teachers' Evaluation. Journal of Child Sexual Abuse, 23(3), 326-344. https://doi.org/10.1080/10538712.2014.888123 
Coolican, H. (1992). Research methods and statistics in psychology. London: Hodder \& Stougtton.

Davis, L. A. (2011). Abuse of Children with Intellectual Disabilities. http://www.thearc.org/page.aspx?pid=2357 (Accessed: 03.10.2017).

Elkins, T. E., Gafford, L. S., Wilks, C. S., Muram, D., \& Golden, G. (1986). A model clinic approach to the reproductive health concerns of the mentally handicapped. Obstetrics and Gynecology, 68(2), 185-188.

Finkelhor, D., Hotaling, G., Lewis, I. A., \& Smith, C. (1990). Sexual abuse in a national survey of adult men and women: prevalence characteristics and risk factors. Child Abuse \& Neglect, 14, 19-28. https://doi.org/10.1016/0145-2134(90)90077-7

Fisher, M. H., Hodapp, R. M., \& Dykens, E. M. (2008). Child abuse among children with disabilities: What we know and what we need to know. International review of research in mental retardation, 35, 251-289. https://doi.org/10.1016/S0074-7750(07)35007-6

Fowler, J. (2008). A Practitioners' tool for the assessment of adults who sexually abuse children. London: Jessica Kingsley Publishers.

Kesici, Ş. \& Baloğlu, M. (2017). Tramva sonrası stres bozukluğu. Ankara: Nobel Yayınları. [Posttraumatic stress disorder. Ankara: Nobel Publishing].

Konuk-Er, R., Girgin-Büyükbayraktar, Ç. \& Kesici, Ş. (2016). Özel eğitime ihtiyacı olan öğrencilere yönelik cinsel eğitim programının geliştirilmesi [Developing the sexual education program for students with special education needs.]. Turkish Journal of Education, 5(4), 224-234.

Kinnear, K. L. (2007). Childhood sexual abuse. A Reference handbook. Santa Barbara, California: ABC-CLIO.

Kliethermes, M. D. (2003). Teacher attitudes and beliefs regarding the occurrence, prevention, impact, and treatment of child sexual abuse: a comparison of beliefs regarding children with a pervasive developmental disorder and non-disabled children. Degree of Doctor of Philosophy, Faculty of the Graduate School of Saint Louis University, St. Louis.

Krohn, J. (2014). Sexual harassment, sexual assault, and students with special needs: crafting an effective response for schools. University of Pennsylvania Journal of Law and Social Change, 17(1), 1-26.

Kvam, M. H. (2004). Sexual abuse of deaf children. A retrospective analysis of the prevalence and characteristics of childhood sexual abuse among deaf adults in Norway. Child Abuse \& Neglect, 28(3), 241-251. https://doi.org/10.1016/j.chiabu.2003.09.017

Liou, W. Y., \& Chen, L. Y. (2016). Special Education Teachers' Perspective on Mandatory Reporting of Sexual Victimization of Students in Taiwan. Sexuality and Disability, 34, 131-143. https://doi.org/10.1007/s11195-016-9436-x

Özteke-Kozan, H. İ., \& Hamarta, E. (2017). Body Image in Emerging Adulthood: The Role of Attachment and Social Appearance Anxiety.Türk Psikolojik Danışma ve Rehberlik Dergisi, 7(48), 63-81.

Smith, N., \& Harrell, S. (2013). Sexual abuse of children with disabilities: A National snapshot. Vera Institute of Justice. www.vera.org/pubs/sexual-abuse-children-with-disabilities (Accessed:10.10.2017).

Stalker, K., \& McArthur, K. (2012). Child abuse, child protection and disabled children: A review of recent research. Child Abuse Review, 21(1), 24-40. https://doi.org/10.1002/car.1154

Tavşancıl, E., \& Aslan, E. (2001). Content analysis and sample practices for verbal, written and other materials. İstanbul: Epsilon Publications

Tharinger, D., Horton, C. B., \& Millea, S. (1990). Sexual abuse and exploitation of children and adults with mental retardation and other handicaps. Child Abuse and Neglect, 14(3), 301-312. https://doi.org/10.1016/0145-2134(90)90002-B

Thornberry, C., \& Olson, K. (2005). The abuse of individuals with developmental disabilities. Developmental Disabilities Bulletin, 33(1-2), 1-19.

Walsh, K., Zwi, K., Woolfenden, S., \& Shlonsky, A. (2015). School-based education pr ogrammes for the prevention of child sexual abuse. Cochrane Database of Systematic Review, 4, 43-80. https://doi.org/10.1002/14651858.CD004380.pub3

Wolcott, H. F. (1990). On seeking-and rejecting-validity in qualitative research. Qualitative inquiry in education: The continuing debate, 121-152. 
World Health Organization (1999). Report of the consultation on child abuse prevention, pp. 15, Geneva (Document WHO/HSC/PVI/99.1) (Accessed:10.04.2016) http://www.who.int/mip2001/files/2017/childabuse.pdf

Yıldırım, A., \& Şimşek, H. (2005). Sosyal bilimlerde nitel araştırma yöntemleri. Ankara: Seçkin Yayıncılık.[Qualitative research methods in social sciences. Ankara: Seçkin Publishing.]

Yıldırım-Doğru, S. S. (2006) Zihin Engelli Çocuklarda Cinsel İstismar. Abant İzzet Baysal Üniversitesi Eğitim Fakültesi Dergisi, 80-91. [Sexual Abuse of Mentally Handicapped Children] Abant İzet Baysal University Journal of Faculty of Education.

Zemp, A. (2002). Sexualized violence against people with developmental disabilities in institutions. Praxis der Kinderpsychologie und Kinderpsychiatrie, 51(8), 610-625.

\section{Copyrights}

Copyright for this article is retained by the author(s), with first publication rights granted to the journal.

This is an open-access article distributed under the terms and conditions of the Creative Commons Attribution license which permits unrestricted use, distribution, and reproduction in any medium, provided the original work is properly cited. 